\title{
Privatization of Selangor Water Supply Distribution: An Analysis from the Political Economy Perspective
}

\author{
Muhammad Shamshinor Abd Azzis ${ }^{1}$ \\ Mohd Azmir bin Mohd Nizah² \\ Sity Daud ${ }^{3}$

\begin{abstract}
Selangor Social Research Institute, Universiti Selangor, Malaysia' Centre of Core Studies, Universiti Sains Islam Malaysia (USIM), Malaysia2; Email: azmirnizah@usim.edu.my School of History, Politics and Strategic Studies, Universiti Kebangsaan Malaysia ${ }^{3}$
\end{abstract}

Doi:10.5901/mjss.2015.v6n6s4p425

\begin{abstract}
The privatization of water supply distribution has been carried out in the Selangor state since 2004. The agreement of treated water distribution concession by the Syarikat Bekalan Air Selangor (SYABAS) demonstrates the existence of conflict from the political economy perspective. First, an active government intervention in the water privatization program is against the aspirations of neoliberalism agenda. Second, within federalism framework which involving federal government and state government from different political party showed a political conflict. Using qualitative method through content analysis approach from Elite Theory and Public Choice Theory, this study argues at two points. First, some distinctive approach applied by both Barisan Nasional (BN) of federal government and Pakatan Rakyat (PR) of state government worth to be discussed. Second, the failure of neoliberal agenda due to approach taken by this two different parties has prevail, but it also argued the importance of the role and state control in privatization program which aimed at gaining political support of relevant political parties. Suggestions are further discussed.
\end{abstract}

Keywords: Politics, Policy Studies, Elite Theory, Political Choice, Electoral Studies.

\section{Introduction}

An efficient water management is a must because it has impacts to the environment as well as the political, economic and social. A global political-economic scenario showed $90 \%$ of worldwide water management is based on public sector ownership and management(Hall \& Lobina, 2009; Klaver, 2012; Prasad, 2006). Objection of the privatization of water management has been highlighted in various cases such as in a large-scale opposition in Bolivia, the ban on the privatization of water management in the Netherlands and movements against the privatization as happened in Stockton, United States and Ghana (Bakker, 2010; Bourguignon \& Sepulveda, 2009; Hall \& Lobina, 2005; Klaver, 2012).

However, a perception of improved water management by the private sector is remained. An improved quality of water supplied, additional investment needed and the expansion of the coverage area is often associated with the impact of the privatization of water management (Prasad, 2006). In Malaysia, scenario showed that the privatization of water management is one of the measures taken by the government towards an efficient water management system that result a shifted its management to the private sector as evidenced in some states. Focus on the state of Selangor, of which has been considered as the most developed state in Malaysia and may generalized Malaysia demographically (Department of Statistics Malaysia, 2010), this study attempt to analyze the privatization strategy implemented as a catalyst for the improvement of state's water management sector. As such, Syarikat Bekalan Air Selangor (SYABAS) has been appointed as a water distribution concession holder for 30 years beginning in 2005 is significant enough to be discussed. This study also is an attempt to highlight conflicting issue, theoretically and practically.

Therefore, water management is a dynamic segment of political economy studies. Policy changes in water management implemented by the government as a respond to the problems faced by citizen. A period of year 2004-2015 shows a significant transformation of water management from the state level. This followed with the introduction of water industry restructuring program in Malaysia, which indicates the presence of intervention policy and conflict between the state and the federal government on water management regime that is often debated. Therefore, a rational analysis of water management, an intervention strategy of government, and consumer satisfaction in the distribution of water supply in Selangor is a significant enough to be study. 


\section{Literature Review}

The main objective of the privatization exercise was to reduce the role of government in the market to increase competition element. The problem of limited government financial resources has led to various problems such as corruption, inefficient service, low quality of service and a range of other political and economic problems. As a result, public facilities becomes a liability to the government as well as the higher government expenses which may led to a decline of political support to the government. Therefore, privatization process is carried out in response to the inefficiency of the government's economic plan. Privatization strategy, which oriented by liberalization and deregulation, is implemented through the reduction or elimination of the role of government in the economy and increased competition. However, the reality is based on the survival of the ruling elite's political power and the aspirations of the planned governance.

Within the framework of neoclassical economics, privatization is carried out with minimum intervention. In contrast, privatization in Malaysia showed an active government intervention (Jomo, 2010, p. 124; Mahathir, 2011, p. 502). As a result, it cause an additional financial burden to the government, creating political dependence between political elites and the economic elites for personal gain(Gomez, 2003, p. 86, 2010, p. 67; Tan, 2008, p. 73) and thus generate a mix of positive and negative implications in terms of quality of service. However, the privatization policy which has become the medium of continuity of power elites and governments still continue to be debated as driving economic growth (Mahathir, 2011, p. 509).

On the other hand, elite theory explains the power held by the ruling and influential groups in society. This elite group serves as a decision-maker on behalf of the government (Janda, Berry, Goldman, Schildkraut, \& Hula, 2013, p. 33) that affect the lives of the governed society (general public). This is based on the scenario that in any society whatsoever (regardless of what ideology and system practiced by the state), every society is divided into two main groups. First, a small group of people who govern (which carry a political task, monopolize and enjoy the powers conferred) and the second, consisting of the majority of other individuals who ruled and dominated by the ruling group. Elite is a minority group in society, but has a greater control over power, wealth, information and organization (Dye, Zeigler, \& Schubert, 2012 , p. 3). Thus, elite is referred to a group of people of having an advantage over the general public, such as the scientists, economists, cultural and religious leaders (Mosca, 1970). In the context of this study, the Selangor state government power applications are reviewed within the scope of the privatization of distribution water supply policy in Selangor.

While the public choice theory explained that each individual are more self-centralized and profit-centered for his own benefits. The motivation of self-interest has become the dominant factor for the government in the planning and implementation of policy (Buchanan \& Wagner, 1977; Buchanan, 1984, p. 13; Niskanen, 1975; Stubbs \& Macatangay, 2002). This is because the government is tend to be more focus on private gain by using reason in the name of public interest (Cavaliere \& Scabrosetti, 2008; Wen \& Yuan, 2010). This study, require the understanding of the public choice theory to analyze the objectives of government intervention, such as the distribution of wealth, market control and financial load in implementing privatization policy. Public choice theory applied in this study based on government interference with private profit-oriented rationale in the implementation of the privatization of water distribution in Selangor.

For economists, public choice theory is often referred to as neoclassical, while the social scientists, public choice theory known as the theory of rational choice. Public choice theory generally supports the important role of the individual against the public in making decisions regarding the implementation of policies of a country. This theory raises an important element in decision-making by an individual of a personal interest as well as methods to maximize personal gain through the society exploitation (Lipset, 1999, p. 35). However, the element of personal interest does not necessarily refer to a negative attitude. According to Cochran \& Malone (2005, p. 67), the rational personal interests mean any individual has their own priority and expected that benefits gained is exceed the costs that required. In terms of making a decision or policy, the theory of public choice is rejecting the common perception that only the private sectors that often make decisions to maximize personal gain while the decision by the ruling elite and bureaucrats are more on the interests and welfare of the community. This is because the desire to maximize personal interests often dominate the attitudes of individuals in market, politics and government (Hodge, 2000, p. 143; Wandling, 2011, p. 37). Political elites too often look for ways to maximize their interest in politics and the benefits of resource development could be achieved in the market (Bakker, 2010). 


\subsection{Syarikat Bekalan Air Selangor Sdn. Bhd.- Distribution concessions in Selangor Water Supply}

Syarikat Bekalan Air Selangor Sdn. Bhd. (SYABAS) is a private company that granted a concession for 30 years to supply treated water to all consumers in Selangor, Kuala Lumpur and Putrajaya. This is confirmed by Water Supply Enactment (2004), which empowers the concessionaire to carry treated water supply distribution services to the public in the mentioned area since January 1, 2005 until December 31, 2035. The concession agreement has involved three parties, that is state governments, the federal government and SYABAS which includes the acquisition of $100 \%$ of mobile assets and equity belongs to Perbadanan Urus Air Selangor Berhad (PUAS) before the privatization take effect. Accordingly, SYABAS is authorized to collect water bills and other charges as agreed under the concession agreement (PNHB, 2005, p. 151).

SYABAS are responsible for managing treated water distribution to consumers through three water concessionaires; that is, Puncak Niaga (M) Sdn. Bhd. (PNSB), Syarikat Pengeluar Air Sungai Selangor Sdn. Bhd. (SPLASH) and Konsortium ABASS Sdn. Bhd (ABASS). This process involved 7.1 million domestic and industrial consumers. It also a responsible for SYABAS to perform a maintenance job for 15,400 kilometers of water pipes, 800 reservoirs and 350 water pump stations (PNHB, 2005, p. 49). This shows a great responsibility borne by SYABAS to ensure the implementation of the water supply distribution system that satisfy the consumers.

Accordingly, the restructuring process of water management in Malaysia is important to be discussed. It involves a number of stakeholders to ensure efficient water management followed by constitutional amendments pertaining the jurisdiction of the federal and state governments in 2005 (Yeoh, 2010, p. 182). From the federal government perspective, the restructuring of the water is one of a strategy to strengthen the authority and control of the federal government in the management of water supply. As for the state government, the restructuring of the water from the State List to the Concurrent List (a responsibility between the federal and state) has received a variety of responses based on the results of the 12th general election in 2008. In the context of this study, the results of the Election of the 12th in 2008 has changed the ruling party in the state from the Barisan Nasional government to the Pakatan Rakyat (PR) coalition which involved Parti Keadilan Rakyat (PKR), Parti Islam Se-Malaysia (PAS) and Democratic Action Party (DAP). Meanwhile, the ruling party at the national level remains to Barisan Nasional. Differences in the ruling coalition at the national level and the state have led to conflict in the strategy of government interference in the process of restructuring the water industry, especially in Selangor.

\section{Research Methodology}

This explanatory study with qualitative design was employed using content analysis method. An extensive analysis from corporate document, newspaper and available primary data is used. Using Elite Theory and Public Choice Theory framework as guiding, findings are presented as below.

\section{Findings and Discussion}

Two conflicting approaches between the Barisan Nasional Selangor state government (prior to GE 12th) with the Pakatan Rakyat Selangor state government (after GE 12th) shows that both governments have responded to the problem water supply in Selangor. The clash between neoliberalism and populist approach is seen as a strategy implemented by the ruling elite in carrying out their responsibilities to solve people's problems. Since water is a very important source of life that affected its citizens, especially the water management issue is one of the key considerations of voters to decide in election, the discussion of the two scenarios are important, and are appropriate to be discussed from the perspective of the elite theory and the theory of public choice.

Prior GE 12th in 2008, Selangor state government of Barisan Nasional, neoliberalism approach has been taken, that is to fully privatize the water supply that is in line with the elite theory. Elite group are responsible for shaping policy and specific policies in their administration. Despite opposition from certain groups, but the state government at that time remains to continue this policy. It is important to note here that the privatization of water is not one of the Barisan Nasional federal government decision, but state leaders instead. This is because there are many more states under the leadership of the Barisan Nasional, did not carry out privatization of water supply, for instance Pulau Pinang state, where effectively manage the water supply, in terms of reasonable rates as well as efficient services. Thus, privatization of water supply in Selangor implemented is based on the aspirations of the Selangor government ruling elite. However, the privatization approach is seemed contrary to the principles of neoliberalism itself, namely the reduction of government interference in the market. This is because in SYABAS privatization, the state government has approximately $30 \%$ shares 
in the company. In addition to that, various forms of assistance and loans provided by the state government to SYABAS. This scenario evidently that the strategy of privatization of water supply in Selangor government involves an active state intervention, as well as 'win-win' situation between the political elites and economic elites.

Whereas, after the 12th General Elections, which resulted the changes in state political leadership from Barisan Nasional (BN) to the Pakatan Rakyat (PR), the state governments have taken the approach to re-acquire the water privatization from SYABAS. One of the approaches taken is through 'Water for People' campaigns. This strategy is to gain political influence in the form of grassroots approach through mass media and civic education, and considered as essential for the ruling elite (Dye et al., 2012, p. 15). This can be evidenced in PR election manifesto, which aimed to provide a free subsidy of $20 \mathrm{~m}^{3}$ water to all domestic individual user accounts and meters. To the state government, the privatization of water supplies by SYABAS has to be canceled due to water tariff structure (as stated in the concession agreement with the Barisan Nasional state government), which portrayed as unfair and oppressing consumer and some other governance issues.

From the public choice theory point of view, privatization approach took by the Barisan Nasional Selangor state government is perceived as only safeguarding the interests of the ruling elite in general. Positively, from different angle, it portrayed that BN are able to solve the water supply that has long time occurred. It also evidenced the interdependency between political elites and economic elites. The public choice theory proponents argued that the ruling elites act in the interests of themselves as 'economic man' whom maximize profits and minimize their costs (Denhardt \& Denhardt, 2015, p. 10). This can be observed through the award of contracts, tender and so on between company and party.

Meanwhile, PR in Selangor also utilized few strategies. For example, the increment of tariff issue structures (once in 3 years-time) is one of the dominant factors that manipulated to expose the preferential of SYABAS concession agreement with the previous government. According to the concession agreement, customers will experience an increment of rate when there is a decrease in the level of unproductive water (that is: the difference in the amount of processed water with amount of charged water bill) that causes the expected increase of 25\% in 2012, 10\% in 2015 and 2019, and 5\% in 2021, 2024, 2027 and 2030. Under the agreement, if the government does not want the users borne the increment of tariff, then, it should be borne by the state government itself. This is the major issue that makes PR state government to decide to re-acquire water supply services from SYABAS.

Furthermore, PR state government also performed their election manifesto of free water subsidy for domestic users in June 2008, even though it led to Kumpulan Darul Ehsan Berhad (KDEB) to bear the burden of subsidy of RM 10.8 million per month, but politically it pays a political advantage to the PR in general. Table 1 summarizes the conflict analysis in the distribution of water supply in Selangor using Elite Theory and Public Choice Theory.

Table 1: Conflict Analysis in Privatization of Water Supply

\begin{tabular}{|c|c|c|}
\hline THEORY/ GOVERNMENT & FEDERAL GOVERNMENT & STATE GOVERNMENT \\
\hline \multirow[t]{2}{*}{ ELITE THEORY } & $\begin{array}{ll}\text { - } & \text { Has an authority in formulating and implementing } \\
& \text { policies } \\
\text { - } & \text { Financial assistance } \\
\text { - } & \text { Constitutional amendments } \\
\text { - } & \text { Amendment of SPAN and the AIPA enactment }\end{array}$ & $\begin{array}{l}\text { - Privatization= state government wants (before GE-12) } \\
\text { - } \quad \text { Public ownership= state government wants (post-GE-12) }\end{array}$ \\
\hline & \multicolumn{2}{|c|}{ THE FAILURE NEOLIBERALISM = STATE ROLE IS RELEVANT IN THE GLOBALIZATION ERA } \\
\hline \multirow[t]{2}{*}{ PUBLIC CHOICE THEORY } & $\begin{array}{l}\text { - The relationship of political elites -economic elite = } \\
\text { profit interdependency/ symbiosis } \\
\text { - Privatization succeeded in giving customer } \\
\text { satisfaction }\end{array}$ & $\begin{array}{l}\text { - } \text { Privatization= Increment of structured rates } \\
\text { VS } \\
\text { - Public Ownership = 'Water for People' Campaign + } \\
\text { Decrement of Structured Tariff + Subsidy } 20 \mathrm{~m}^{3}\end{array}$ \\
\hline & \multicolumn{2}{|l|}{ POLITICAL SUPPORT } \\
\hline
\end{tabular}

\section{Conclusion}

The privatization of water supply distribution in Selangor has shown conflict in strategy and approach by the federal state government. This study analyzed in two major implications. First, personal interest is the prime factor for elite's behaviour and decision, which is parallel with the foundation of public choice theory. Elite group have used privatization process to strengthen their political influence through symbiotic relationships and interdependencies between economic elites (conglomerates) and the political elite, as well as the political elite itself has become the economic elite. This can be evidenced through acquisition of stocks, mutual concession agreement and financial risk protection by the government in the event of a loss. The political elite also gained non-material benefit, such as an increased political influence for own selves and party. Second, political elites manipulate the weaknesses of the privatization and received benefits in the form 
of political support. This can be seen in the increased of influence on citizens and civil society by portraying the weaknesses of privatization agenda that has profit on elite group and burdened of society. As a result, an enhanced political image and political influence may benefit political elite that provide an alternative in managing public affairs, and ease public difficulties.

\section{References}

Bakker, K. (2010). Privatizing Water: Governance Failure and the World's Urban Water Crisis. New York: Cornell University Press.

Bourguignon, F., \& Sepulveda, C. (2009). Privatization in Development Some Lessons from Experience. Policy Research Working Paper.

Buchanan, J. M. (1984). Politics witout Romance: A Sketch of Positive Public ChoiceTheory and Its Normative Implications. In J. M. Buchanan \& R. D. Tollison (Eds.), The Theory of Public Choice--II (pp. 11-23). Michigan: The University of Michigan Press.

Buchanan, J. M., \& Wagner, R. E. (1977). Democracy in Deficit: The Political Legacy of Lord Keynes. New York: Academic Press.

Cavaliere, A., \& Scabrosetti, S. (2008). Privatization and efficiency: From principals and agents to political economy. Journal of Economic Surveys, 22(4), 685-710. doi:10.1111/j.1467-6419.2007.00546.x

Cochran, C. L., \& Malone, E. F. (2005). Public Policy :Perspectives and Choices. Columbia: Lynne Rienner Publishers.

Denhardt, J. V, \& Denhardt, R. B. (2015). The New Public Service: Serving, Not Steering. New York: Routledge.

Department of Statistics Malaysia. (2010). Population Distribution and Basic Demographic Characteristics.pdf. Putrajaya.

Dye, T., Zeigler, H., \& Schubert, L. (2012). The Irony of Democracy: An Uncommon Introduction to American Politics. Boston: Cengage Learning.

Gomez, E. T. (2003). Political Business in Malaysia: Party Factionalism, Corporate Development, and Economic Crisis. In E. T. Gomez (Ed.), Political Business in East Asia. London: Routledge.

Gomez, E. T. (2010). Financing Politics in Malaysia. In A. Butler (Ed.), Paying for Politics: Party Funding and Political Change in South Africa and the Global South (pp. 53-80). Sunnyside,Auckland Park: Jacana Media \& Konrad Adenauer.

Hall, D., \& Lobina, E. (2005). The Relative Efficiency of Public and Private Sector Water (Vol. 44). London.

Hall, D., \& Lobina, E. (2009). The Private Sector in Water in 2009. London.

Hodge, G. A. (2000). Privatization: An International Review of Performance (Theoretical Lenses on Public Policy). Boulder: West View Press.

Janda, K., Berry, J., Goldman, J., Schildkraut, D., \& Hula, K. (2013). The Challenge of Democracy: American Government in Global Politics. Cengage Learning.

Jomo, K. S. (2010). Warisan Ekonomi Mahathir. Kuala Lumpur: Utusan Publications \& Distributors.

Klaver, I. J. (2012). Water, Cultural Diversity, and Global Environmental Change. (B. R. Johnston, L. Hiwasaki, I. J. Klaver, A. Ramos Castillo, \& V. Strang, Eds.)Water, Cultural Diversity, and Global Environmental Change. Dordrecht: Springer Netherlands. doi:10.1007/978-94-007-1774-9

Lipset, S. M. (1999). Introduction by Seymour Martin Lipset. In R. Michels (Ed.), Political Parties: A Sociological Study of the Oligarchical Tendencies of Modern Democracy (pp. 15-42). New Jersey: Transaction Publishers.

Mahathir, . Mohamad. (2011). A Doctor in the House: The Memoirs of Tun Dr Mahathir Mohamad. Petaling Jaya, Selangor: MPH Group Publishing.

Mosca, G. (1970). The Ruling Class. New York: McGraw-Hill Companies.

Niskanen, W. A. (1975). Bureaucrats and Politicians. Journal of Law and Economics, 18(3), 617-643.

PNHB. (2005). Laporan Tahunan Puncak Niaga Holdings Berhad 2005. Shah Alam.

Prasad, N. (2006). Privatisation results: Private sector participation in water services after 15 years. Development Policy Review, 24(6), $669-692$.

Stubbs, P., \& Macatangay, R. E. A. (2002). The British experience of privitization and regulation of the electricity industry, and some lessons for the Philippines. Journal of the Asia Pacific Economy, 7(1), 113-136.

Tan, J. (2008). Privatization in Malaysia: Regulation, Rent-Seeking and Policy Failure. London: Routledge.

Wandling, R. A. (2011). Rationality and Rational Choice. In 21st Century Political Science: A Reference Handbook (pp. 34-43). Thousand Oaks,CA: SAGE Publications Inc. doi:10.4135/9781412979351

Wen, J.-F., \& Yuan, L. (2010). Optimal Privatization of Vertical Public Utilities. Canadian Journal of Economics, 43(3), 816-831. doi:10.1111/j.1540-5982.2010.01596.x

Yeoh, T. (2010). The Pakatan Rakyat Selangor State Administration: Present and Future Challenges on the Road to Reform. The Round Table:The Commonwealth Journal of International Affairs, 99(407), 177-193. doi:10.1080/00358531003656347. 